\title{
Hak Atas Informasi Terhadap Bahan Kosmetik Pengguna Jasa Klinik Kecantikan Berdasarkan Undang - Undang Nomor 8 Tahun 1999 Tentang Perlindungan Konsumen
}

\begin{abstract}
Jihan Nur Rahmah*
Abstrak

Konsumen mempunyai hak atas informasi terhadap barang yang dikonsumsinya, namun dalam praktiknya jasa klinik kecantikan masih banyak ditemui melanggar aturan UUPK yaitu tidak terpenuhinya hak atas informasi konsumen terhadap bahan kandungan kosmetik yang digunakan. Adapun permasalahan bagaimana pelaksanaan pemenuhan hak atas informasi bahan kosmetik dan bagaimana penyelesaian sengketa atas pelanggaran yang dilakukan Jasa Klinik Kecantikan yang tidak melengkapi informasi terhadap produk kecantikan. Tujuan yaitu untuk memperoleh informasi pelaksanaan pemenuhan hak atas informasi bahan kosmetik dan penyelesaian sengketa atas pelanggaran yang dilakukan Jasa Klinik Kecantikan yang tidak melengkapi informasi terhadap produk kecantikan. Kegunaannya yaitu dapat memberikan informasi pelaksanaan pemenuhan hak atas informasi bahan kosmetik dan penyelesaian sengketa atas pelanggaran yang dilakukan Jasa Klinik Kecantikan yang tidak melengkapi informasi terhadap produk kecantikan. Adapun metode penelitian yang digunakan yuridis normatif. Dari hasil penelitian ditemukan masih banyaknya klinik yang belum memenuhi kewajibannya selaku pelaku usaha dimana tidak terpenuhinya hak atas informasi atas bahan kosmetik yang digunakan. Penyelesaian sengketa dapat ditempuh diluar dan di dalam pengadilan. Dimana diluar pengadilan dilakukan dengan cara mediasi antara konsumen dengan pelaku usaha, dapat juga dilakukan dengan cara konsilidasi dan arbitrase. Selanjutnya jika tidak terselesaikan maka dapat ditempuh melalui pengadilan dimana diatur dalam pasal 45 UUPK. Kesimpulannya yaitu masih banyak jasa klinik kecantikan yang tidak memberikan hak informasi terhadap bahan kandungan yang ada dalam kosmetik dan penyelesaian sengketa atas pelanggaran yang dilakukan oleh Jasa Klinik Kecantikan atas informasi yang tidak dilengkapi sengketa konsumen dapat ditempuh melalui pengadilan atau di luar pengadilan berdasarkan pilihan sukarela para pihak yang bersengketa.
\end{abstract}

Kata Kunci: Hak Atas Informasi, Bahan Kosmetik.

*E-mail: jihan_rahmah@yahoo.com 


\title{
The Right To Information In Regards To Cosmetic Usage Practiced By Beauty Clinics Based On Law Number 8 Of 1999 With Consumer Protection
}

\begin{abstract}
Consumers have the right to information on the goods they consume, but in practice beauty clinic services are still commonly found to violate the UUPK rules, namely not fulfilling the right to consumer information on cosmetic ingredients used. The problem is how the fulfillment of the right to information on cosmetic ingredients and how to resolve disputes over violations by Beauty Clinic Services that do not supplement information on beauty products. The purpose is to obtain information on the implementation of fulfilling the right to information on cosmetic ingredients and dispute resolution for violations committed by Beauty Clinic Services that do not supplement information on beauty products. Its usefulness is to provide information on the implementation of the fulfillment of the right to information on cosmetic ingredients and dispute resolution for violations by Beauty Clinic Services that do not supplement information on beauty products. The research method used is normative juridical. From the results of the study found that there are still many clinics that have not fulfilled their obligations as a business actor where the right to information on the cosmetic ingredients that are not fulfilled is fulfilled. Dispute resolution can be done outside and in court. Where outside the court is carried out by means of mediation between consumers and business actors, it can also be done by way of consolidation and arbitration. Furthermore, if it is not resolved, it can be reached through a court which is regulated in article 45 of the UUPK. The conclusion is that there are still many beauty clinic services that do not provide information rights to the ingredients contained in cosmetics and dispute resolution for violations committed by Beauty Clinic Services for information that is not equipped with consumer disputes can be reached through the court or outside the court based on the voluntary choice of the parties the disputes.
\end{abstract}

Keywords : Right to Information; Cosmetic ingredients.

\section{Pendahuluan}

Setiap wanita menginginkan kulit sehat dan bersih, tidak kurang diantaranya berusaha mendapatkan keinginan tersebut dengan cara memakai suatu produk kecantikan yang diperjual belikan oleh salah satu jasa klinik kecantikan. Konsumen khususnya wanita percaya apabila ia mengkonsumsi produk kosmetik yang disediakan oleh salah satu jasa klinik kecantikan dapat mempercepat ia mendapatkan kulit cantik seperti yang ia inginkan.

Namun banyak sekali pihak konsumen yang tertipu daya dengan suatu produk yang menjanjikan dengan cara tidak memperhatikan bahan produk yang 
dikonsumsinya. Karena telah percaya akan khasiat barang yang diberikan oleh pihak produsen atau pihak jasa klinik kecantikan. Kurangnya kesadaran produsen pada pemberian hak atas informasi terhadap suatu produk bahan kosmetik yang diperjual belikan mengakibatkan kerugian pada konsumen atas barang yang dikonsumsinya.

Pemberian hak atas informasi yang cenderung berat sebelah, mengakibatkan kerugian bagi kepentingan konsumen wanita pada khususnya, baik secara langsung maupun tidak lansung. Pelaku usaha juga sering mengabaikan hak-hak konsumen, baik dalam memberikan pelayanan pada masyarakat maupun dalam penjualan produk, penggunaan zat tambahan kosmetika yang dilarang atau tidak mengikuti dosis yang ditentukan.

Pada dasarnya bagi konsumen yang menjadi pertimbangan tidak hanyalah penampilan, melainkan kejujuran mengenai kondisi dan jaminan kosmetik yang diberikan oleh jasa klinik kecantikan tersebut. Sesuatu yang tampak bersih belum tentu bagus untuk kesehatan. Karena itulah setiap konsumen jasa klinik kecantikan berhak serta perlu mendapatkan hak dan informasi yang sejelasjelasnya mengenai kualitas, isi, serta dampak apa yang akan terjadi kelak bila menggunakan produk tersebut. Namun apakah konsumen sudah mendapatkan informasi yang benar, jelas, dan jujur mengenai pemakaian produk kecantikan yang disediakan oleh jasa klinik kecantikan?

Kondisi konsumen yang banyak dirugikan, memerlukan peningkatan upaya untuk melindunginya, sehingga hak-hak konsumen dapat ditegakkan. Salah satu dari hak konsumen adalah hak atas informasi yang benar, jelas dan jujur mengenai kondisi dan jaminan barang dan atau jasa. ( Sinar Grafika, 2001:5)

Bahwa informasi merupakan hal penting bagi konsumen, karena melalui informasi tersebut konsumen dapat memilah secara benar produk kecantikan yang mana menjadi kebutuhan serta aman apabila dikonsumsi dalam jangka panjang. Informasi memegang peranan penting terhadap suatu barang. Informasi yang benar dan bertanggungjawab merupakan hak tiap konsumen sebelum ia mengambil suatu keputusan untuk mengadakan, menunda, atau tidak mengadakan transaksi bagi kebutuhan hidupnya. Didalam Pasal 1 Undang- 
Undang Nomor 8 Tahun 1999 tentang Perlindungan Konsumen dikatakan bahwa Perlindungan Konsumen adalah segala upaya yang menjamin kepastian hukum untuk memberi perlindungan kepada konsumen.

Kosmetik yang mengandung zat-zat yang berbahaya seperti mercury yang beredar di masyarakat akan mempunyai dampak negatif yang salah satunya dapat menyebabkan kanker, dampak negatif tidak hanya berpengaruh pada pengguna kosmetik itu sendiri, tetapi juga bagi jasa klinik kecantikan itu sendiri. Dikatakan berpengaruh kepada jasa klinik, karena akan menimbulkan ketidakpercayaan publik terhadap kosmetik jasa klinik tersebut. Hilangnya kepercayaan publik akan menurunkan daya beli masyarakat terhadap kosmetik jasa klinik, yang secara bersamaan akan menurunkan daya produktivitas jasa tersebut.

Melalui Undang-Undang Nomor 8 Tahun 1999 tentang Perlindungan Konsumen, Pemerintah Indonesia mengatur hak-hak konsumen yang harus dilindungi. Undang-Undang Perlindungan Konsumen bukanlah anti terhadap produsen, namun sebaliknya malah merupakan apresiasi terhadap hak-hak konsumen secara universal.(Sofie, 2002:12)

Berdasarkan latar belakang tersebut diatas, maka permasalahanpermasalahan yang diteliti ialah :

a. Bagaimanapelaksanaan pemenuhan hak atas informasi bahan kosmetik oleh pelaku usaha jasa klinik kecantikan yang diatur dalam Undang-Undang Nomor 8 Tahun 1999 tentang Perlindungan Konsumen?

b. Bagaimana penyelesaian sengketa atas pelanggaran yang dilakukan oleh Jasa Klinik Kecantikan yang tidak melengkapi informasi terhadap produk kecantikannya?

\section{Pembahasan}

A. Pelaksanaan Pemenuhan Hak Atas Informasi Bahan Kosmetik Dalam Undang-Undang Nomor 8 Tahun 1999 Tentang Perlindungan Konsumen 


\section{Hak Informasi Bahan Kosmetik dalam UUPK}

Dalam Undang-Undang Nomor 8 Tahun 1999 Tentang Perlindungan Konsumen tidak ada pengaturan secara khusus terhadap hak informasi atas bahan kosmetika, sehingga dalam Undang-Undang ini tidak terdapat perbedaan antara hak informasi pada bahan kosmetik maupun hak informasi pada produk lainnya.

Informasi barang atau jasa konsumen dapat diperoleh dari berbagai sumber dan dalam berbagai bentuk. Konsumen biasanya mendapatkan sumber utama informasi yang disediakan oleh pelaku usaha (Produsen/Distributor) produk. Informasi tersebut disampaikan dalam rangka memperkenalkan dan memasarkan produk yang harus sesuai dengan suatu peraturan perundang-undangan yang berkaitan. Dan informasi juga dapat pula diperoleh dari kalangan konsumen sendiri baik melalui (organisasi-organisasi konsumen) maupun dari sumber pemerintah.

Informasi dapat berbentuk Label/Etiket pada Produk, serta Kegiatan yang meningkatkan penjualan dengan penggunaan pamflet, brosur, leaflets, selembaran, dan kegiatan hubungan kemasyarakatan dengan upacaraupacara pengguntingan pita, pelepasan produk (ekspor) perdana, pengadaan penyerahan hadiah atau sumbangan maupun periklanan atau lain-lain, caracara memperkenalkan produk pada konsumen, mempertahankan dan atau meningkatkannya. (A.Z Nasution,1995:40)

Berdasarkan penelitian empiris yang dilakukan dengan cara menyebarkan kuesioner melalui google form dimana diisi oleh 110 responden, dimana 92,7\% wanita dan 7,3\% pria, yang berdomisili di DKI Jakarta, dimana $76,4 \%$ berusia 20 sampai 25 tahun, $10 \%$ berusia 25 sampai 30 tahun, 7,3\% berusia 15 sampai 20 tahun, dimana 50\% yaitu mahasiswa, serta $25,9 \%$ kantoran atau pegawai, serta $25 \%$ ibu rumah tangga, dimana responden adalah pengguna jasa klinik kecantikan di kota Jakarta yaitu klinik berinisial E, LB, SM, N, TA, LM, ML,CC,Z, dan MA.

Adapun tanggapan pengguna Jasa Klinik Kecantikan dari 110 orang, bahwa $49,1 \%$ diantaranya tidak mendapatkan informasi bahan produk 
kosmetik, 15,5\% diantaranya keliru apakah sudah mendapatkan informasi terhadap bahan kosmetik dari Jasa Klinik kecantikan. Hal ini pelaku usaha Jasa Klinik Kecantikan sudah melanggar ketentuan Pasal 4 Undang-Undang Nomor 8 Tahun 1999 tentang Perlindungan konsumen, dimana konsumen memiliki hak atas informasi yang benar, jelas dan jujur mengenai kondisi dan jaminan barang.

Hasil penelitian penulis di Yayasan Lembaga Konsumen Indonesia (YLKI) menyatakan sangat minimnya laporan terkait kesehatan terutama kecantikan mengenai kosmetik. Ini sesuai dengan hasil wawancara penulis dengan Eva Rosita selaku Staf Penelitian YLKI, dimana beliau mengatakan bahwa dari tahun 2014 sampai dengan 2018 sangat minimnya laporan mengenai kesehatan terutama pemenuhan hak atas informasi terhadap bahan kosmetik.

Dari hasil penelitian penulis 110 orang $57,3 \%$ diantaranya sebagai pengguna jasa klinik kecantikan yang melakukan penggunaan kosmetik yang tidak terpenuhi hak informasi atas bahan kosmetik tersebut. Penulis berpendapat bahwa minimnya laporan ke YLKI ataupun badan lainnya karena ketidak tahuan masyarakat terhadap UUPK yang mengatur hak-hak dan kewajiban konsumen serta pelaku usaha yang berdampak ketidak tahuan bagaimana cara untuk mengadukan perihal tersebut.

Menurut penulis, masih minimnya pengetahuan masyarakat tentang Undang-undang perlindungan konsumen yang berpengaruh terhadap kurangnya perhatian konsumen terhadap hak nya sebagai konsumen atas mengkonsumsi suatu produk. 37,3\% dari 110 orang diantaranya menjawab ingin sekali melakukan penggugatan atas pelanggaran yang telah dilakukan oleh jasa klinik kecantikan namun $42,1 \%$ diantaranya yang mungkin akan melakukan penggugatan yang mungkin memiliki beberapa alasan tertentu yang mengurungkan untuk tidak terjadi pelaporan seperti minimnya informasi bagaimana cara pelaporan, banyaknya biaya yang harus dikeluarkan apabila membuat suatu pelaporan, atau dapat juga karna 
kurangnya kepercayaan masyarakat terhadap aparat penegak hukum yang akan memperlancar pelaporan dengan tempo waktu yang singkat.

\section{Pelaksanaan Pemenuhan Hak Atas Informasi Bahan Kosmetik Oleh Pelaku Usaha Jasa Klinik Kecantikan Yang Diatur Dalam Undang- Undang Nomor 8 Tahun 1999 Tentang Perlindungan Konsumen}

Pemberian hak atas informasi telah diatur di dalam Pasal 4 UndangUndang Perlindungan Konsumen yang merumuskan sejumlah hak penting konsumen. Menurut Pasal 4, ada sembilan hak dari konsumen, delapan diantaranya hak yang secara eksplisit diatur dalam UUPK dan satu hak lainnya diatur dalam ketentuan peraturan perundang-undangan lainnya. Hak-hak tersebut adalah:

a. Hak atas kenyamanan, keamanan dan keselamatan atas barang dan jasa;

b. Hak untuk memilih barang dan jasa;

c. Hak mendapatkan informasi yang benar, jelas, dan jujur atas barang dan jasa.

d. Hak untuk didengar pendapat dan keluhannya;

e. Hak untuk mendapatkan bantuan hukum (advokasi), perlindungan dan penyelesaian sengketa;

f. Hak dalam pembinaan dan pendidikan konsumen;

g. Hak untuk diberlakukan secara benar, jujur dan tidak diskriminatif;

h. Hak untuk mendapatkan kompensasi atas barang atau jasa yang merugikan;

i. Hak-hak yang ditentukan dalam perundang-undangan lain.

Berdasarkan ketentuan tersebut dapat dilihat bahwa hak atas informasi yang benar, jelas dan jujur atas barang dan jasa telah secara tegas diatur oleh UUPK dalam Pasal 4 huruf c. Namun dalam prakteknya masih banyak Jasa Klinik Kecantikan yang tidak dapat memenuhi kewajibannya selaku pelaku usaha yang seharusnya memenuhi setiap hak konsumen. 
Hak konsumen merupakan kewajiban yang harus dipenuhi oleh setiap pelaku usaha. Hal itu jelas telah diatur didalam Peraturan Undang-Undang Perlindungan Konsumen yang diatur dalam Pasal 7 UUPK yaitu memberikan tujuh kewajiban pelaku usaha, yakni:

a. Beritikad baik dalam kegiatan usaha;

b. Memberi informasi yang benar, jelas dan jujur mengenai kondisi dan jaminan barang atau jasa, termasuk penjelasan tentang penggunaan, perbaikan dan pemeliharaan;

c. Melayani konsumen secara benar, jujur dan tidak diskriminatif;

d. Menjamin mutu barang atau jasa berdasarkan ketentuan standart mutu yang berlaku;

e. Memberi kesempatan kepada konsumen menguji barang atau jasa dan memberi jaminan/garansi atas barang yang diperdagangkan;

f. Memberi ganti rugi atau kompensasi atas kerugian yang timbul dari pemakaian barang atau jasa yang diperdagangkan;

g. Memberi ganti rugi atau kompensasi atas kerugian karena tidak sesuai perjanjian.

Setiap jasa klinik kecantikan wajib memenuhi standarisasi klinik kecantikan yaitu memiliki konsultan ahli, tempat yang sesuai, peralatan yang baik dan aman, terapis yang berpengalaman, produk yang aman, serta pelayanan dan garansi.

Tanggung jawab pelaku atas kerugian konsumen dalam UndangUndang tentang Perlindungan Konsumen diatur khusus dalam satu bab XI, mulai dari Pasal 19 sampai dengan Pasal 28. Dari sepuluh pasal tersebut dapat dipilih sebagai berikut:

a. Tujuh pasal, yaitu Pasal 19, Pasal 20, Pasal 21, Pasal 24, Pasal 25, Pasal 26, dan Pasal 27, yang mengatur pertanggung jawaban pelaku usaha;

b. Dua pasal, yaitu Pasal 22 dan Pasal 28 yang mengatur pembuktian; 
c. Satu pasal, yaitu Pasal 23 yang mengatur penyelesaian sengketa dalam hal pelaku usaha tidak memenuhi kewajibannya untuk memberikan ganti rugi kepada konsumen. (Gunawan Wijaya dan Ahmad Yani, 2003 $: 65)$

Produk kosmetika yang dijual dipasaran memiliki standar ketentuan yang harus ada disetiap kemasannya seperti adanya label komposisi, label halal dan nomor izin edar namun berdasarkan praktek dilapangan penelitian penulis disini pelaku usaha Jasa Klinik Kecantikan belum memiliki ketentuan standar yang berlaku yaitu menjual kosmetiknya tanpa disertai label komposisi, maupun nomor izin edar yang seharusnya ditempelkan dalam setiap kemasan.

\section{B. Penyelesaian Sengketa Atas Pelanggaran Yang Dilakukan oleh Jasa Klinik Kecantikan Yang Tidak Melengkapi Informasi Terhadap Produk Kecantikannya.}

Penyelesaian sengketa secara patut merupakan harapan setiap individu yang sedang bersengketa. Salah satunya adalah sengketa antara konsumen dan pelaku usaha. Penyelesaian sengketa di bidang konsumen merupakan kebijakan yang baik dalam upaya pemberdayaan (empowerment system). Upaya pemberdayaan konsumen merupakan bentuk kesadaran mengenai karakteristik khusus dunia konsumen, yaitu adanya perbedaan kepentingan yang tajam antara pihak yang berbeda posisi tawarnya (bargaining position). (NHT Siahaan, 2005:202)

Sengketa konsumen adalah sengketa antara konsumen dengan pelaku usaha (publik atau privat) tentang produk konsumen, barang atau jasa konsumen tertentu, (A.Z Nasution,1995:229)dengan penyelesaiannya sesuai dengan hukum positif yang berlaku terutama undang-undang yang bersifat khusus seperti Undang-Undang Perlindungan Konsumen, sebaya upaya untuk memberikan perlindungan terhadap konsumen.

Penyelesaian sengketa secara hukum bertujuan untuk memberikan kenyamanan terhadap kedua belah pihak agar hak-hak kedua belah pihak 
terlaksana dengan baik agar terciptanya keadilan bagi para pelaku usaha dan konsumen.

Salah satu alternatif penyelesaian sengketa konsumen adalah melalui jalur non litigasi yaitu forum musyawarah antara pelaku usaha dengan konsumen untuk mencapai kesepakatan berdasarkan Pasal 45 ayat 2 Undang-Undang Perlindungan Konsumen yaitu : "Penyelesaian sengketa konsumen dapat ditempuh melalui pengadilan atau di luar pengadilan berdasarkan pilihan sukarela para pihak yang bersengketa"

Ketentuan pada Pasal 45 ayat 2 UUPK ini memungkinkan konsumen langsung bernegoisasi dengan pelaku usaha sehingga sengketa konsumen dapat diselesaikan antara kedua belah pihak dengan jalan damai. Penyelesaian sengketa diluar pengadilan ini adalah ketika konsumen menuntut pergantian kerugian secara langsung kepada pelaku usaha dengan jalan damai. Pergantian secara langsung dipertegas pada Pasal 19 UUPK. Pergantian secara langsung dipertegas pada Pasal 19 UUPK yaitu:

(1) Pelaku usaha bertanggung jawab memberikan ganti rugi atas kerusakan, pencemaran, dan/atau kerugian konsumen akibat mengkonsumsi barang dan/atau jasa yang dihasilkan atau diperdagangkan.

(2) Ganti rugi sebagaimana dimaksud pada ayat (1) dapat berupa pengembalian uang atau penggantian barang dan/atau jasa yangsejenis atau setara nilainya, atau perawatan kesehatan dan/atau pemberian santunan yang sesuai dengan ketentuan peraturan perundang-undangan yang berlaku.

(3) Pemberian ganti rugi dilaksanakan dalam tenggang waktu 7 (tujuh) hari setelah tanggal transaksi.

(4) Pemberian ganti rugi sebagaimana dimaksud pada ayat (1) dan ayat (2) tidak menghapuskan kemungkinan adanya tuntutan pidana berdasarkan pembuktian lebih lanjut mengenai adanya unsur kesalahan.

(5) Ketentuan sebagaimana dimaksud pada ayat (1) dan ayat (2) tidak berlaku apabila pelaku usaha dapat membuktikan bahwa kesalahan tersebut merupakan kesalahan konsumen. 
Berdasarkan ketentuan ini maka seorang konsumen dapat secara langsung menghubungi pelaku usaha untu meminta kerugian yang di derita dari suatu produk baik berupa barang atau jasa. Bentuk tuntutan kerugian dapat berupa pengembalian uang, pergantian barang, perawatan kesehatan, dan juga santunan sesuai dengan kerugian yang diderita oleh konsumen. UUPK membatasi waktu pengaduan setelah 7 hari saja, hal ini menyatakan bahwa penyelesaian sengketa seperti ini adalah penyelesaian sengketa sederhana tanpa melalui pemeriksaan mendalam, asalkan tercapainya kesepakatan antara para pihak.

Berdasarkan Pasal 52 huruf a UUPK bahwa BPSK akan menyelesaikan sengketa konsumen dengan jalan melalui mediasi, konsiliasi dan arbitrase yaitu:

1. Mediasi

Mediasi merupakan cara penyelesaian sengketa yang fleksibel dan tidak mengikat serta melibatkan pihak netral yaitu mediator, yang memudahkan negoisasi antara para pihak untuk membantu mereka dalam mencapai suatu kesepakatan.(Mulyana W. Kusuma, 1994:5) Kesepakatan dapat dilakukan sebelum timbulnya sengketa, yaitu dengan memasukan sebagai kemudian para pihak membuat kesepakatan untuk menyerahkan penyelesaian melalui mediasi.

Keuntungan penyelesaian sengketa melalui mediasi adalah karena cara pendekatan penyelesaian diarahkan pada kerja sama untuk mencapai kompromi, sehingga masing-masing pihak tidak perlu mematahkan fakta dan bukti yang mereka miliki, serta tidak membela dan mempertahankan kebenaran masing-masing. Sehingga pembuktian tidak lagi menjadi beban yang memberatkan para pihak (Yahya Harahap, 1997 : 393).

2. Konsiliasi

Konsiliasi untuk menyelesaikan konsumen dengan pelaku usaha berdasarkan UUPK. Konsiliasi memiliki kesamaan dengan arbitrase yaitu menyerahkan kepada pihak ketiga untuk memberikan pendapatnya tentang sengketa yang disampaikan oleh para pihak, akan tetapi pendapat dari konsiliator tidak mengikat sebagai mana yang ada pada arbitrase.(Aulia Muthiah, 2015:233). 
Penyelesaian sengketa dengan langkah arbitrase adalah salah satu cara mempercepat sengketa konsumen, yaitu melalui lembaga BPSK, yang putusannya dinyatakan final dan mengikat . Namun UUPK masih membuka kemungkinan pihak yang keberatan atas putusan tersebut untuk mengajukan keberatan kepada Pengadilan Negeri, hanya saja pihak yang tidak puas atas putusan Pengadilan Negeri dan juga dapat melakukan upaya kasasi ke Mahkamah Agung dalam tempo waktu 14 hari.

Penyelesaian sengketa ini sama saja dengan jalur litigasi, perbedaannya hanya terletak pada tidak dikenalnya upaya hukum banding terhadap putusannya, sehingga putusan BPSK jika ada pihak yang keberatan dapat mengajukan kasasi kepada Mahkamah Agung.

3. Arbitrase

Penyelesaian sengketa dengan langkah arbitrase adalah salah satu cara mempercepat sengketa konsumen, yaitu melalui lembaga BPSK, yang putusannya dinyatakan final dan mengikat . Namun UUPK masih membuka kemungkinan pihak yang keberatan atas putusan tersebut untuk mengajukan keberatan kepada Pengadilan Negeri, hanya saja pihak yang tidak puas atas putusan Pengadilan Negeri dan juga dapat melakukan upaya kasasi ke Mahkamah Agung dalam tempo waktu 14 hari.

Penyelesaian sengketa ini sama saja dengan jalur litigasi, perbedaannya hanya terletak pada tidak dikenalnya upaya hukum banding terhadap putusannya, sehingga putusan BPSK jika ada pihak yang keberatan dapat mengajukan kasasi kepada Mahkamah Agung.

Penyelesaian sengketa antara konsumen dengan pelaku usaha juga dapat diselesaikan dengan jalur litigasi. Litigasi berasal dari bahasa Inggris "litigation" yang artinya pengadilan. Tugas dari pengadilan adalah menyelesaikan sengketa yang timbul dan akhirnya menjatuhkan putusan (constitutive) yang seadil-adilnya. (Intan Nur Rahmawanti dan Rukiyah Lubis, 2014:69) 
Berdasarkan Pasal 48 UUPK penyelesaian sengketa konsumen dengan pelaku usaha dapat diselesaikan melalui pengadilan, yaitu: "Penyelesaian sengketa konsumen melalui pengadilan mengacu pada ketentuan tentang Peradilan umum yang berlaku dengan memperhatikan ketentuan pada Pasal 45".

Dengan ketentuan UUPK ini maka, penyelesaian sengketa konsumen melalui pengadilan yang mengacu pada ketentuan peradilan umum, sehingga hukum acara yang dipakai adalah berdasarkan Herziene Inlands Regeling (HIR) dan juga Rechtsreglemen Buitengewesten ( $\mathrm{RBg})$.

Sengketa konsumen memang lebih diarahkan kepada sengketa perdata namun tanggung jawab pidana juga tidak dapat dihapuskan, sesuai dengan tatanan hukum hukum pidana. Hal ini secara jelas disebutkan pada Pasal 45 UUPK yaitu:

(1) Setiap konsumen yang dirugikan dapat menggugat pelaku usaha melalui lembaga yang bertugas menyelesaikan sengketa antara konsumen dan pelaku usaha atau melalui peradilan yang berada di lingkunganperadilan umum.

(2) Penyelesaian sengketa konsumen dapat ditempuh melalui pengadilan atau di luar pengadilan berdasarkan pilihan sukarela para pihak yang bersengketa.

(3) Penyelesaian sengketa di luar pengadilan sebagaimana dimaksud pada ayat (2) tidak menghilangkan tanggung jawab pidana sebagaimana diatur dalam Undang-undang.

(4) Apabila telah dipilih upaya penyelesaian sengketa konsumen di luar pengadilan, gugatan melalui pengadilan hanya dapat ditempuh apabila upaya tersebut dinyatakan tidak berhasil oleh salah satu pihak atau oleh para pihak yang bersengketa.

Berdasarkan Pasal 45 UUPK ini secara jelas menyatakan tidak menghilangkan tanggung jawab pidana, namun memang sengketa konsumem kebanyakkan adalah sengketa perdata yaitu konsumen yang menderita kerugian. Dalam hukum acara perdata yang berlaku di Indonesia dikenal asas "hakim bersifat menunggu" yang artinya bahwa inisiatif berperkara datang dari pihak- 
pihak yang berkepentingan. Dalam UUPK pihak-pihak yang dimaksud berkepentingan adalah diatur dalam Pasal 46 UUPK yaitu:

(1) Gugatan atas pelanggaran pelaku usaha dapat dilakukan oleh:

a. seorang konsumen yang dirugikan atau ahli waris yang bersangkutan;

b. sekelompok konsumen yang mempunyai kepentingan yang sama;

c. lembaga perlindungan konsumen swadaya masyarakat yang memenuhi syarat, yaitu berbentuk badan hukum atau yayasan, yang dalam anggaran dasarnya menyebutkan dengan tegas bahwa tujuan didirikannya organisasi tersebut adalah untuk kepentingan perlindungan konsumen dan telah melaksanakan kegiatan sesuai dengan anggaran dasarnya;

d. pemerintah dan/atau instansi terkait apabila barang dan/atau jasa yang dikonsumsi atau dimanfaatkan mengakibatkan kerugian materi yang besar dan/atau korban yang tidak sedikit.

(2) Gugatan yang diajukan oleh kelompok konsumen, lembaga perllindungan konsumen swadaya masyarakat atau pemerintah sebagaimana dimaksud pada ayat (1) huruf b, huruf c, atau huruf d diajukan kepada peradilan umum.

(3) Ketentuan lebih lanjut mengenai kerugian materi yang besar dan/atau korban yang tidak sedikit sebagaimana dimaksud pada ayat (1) huruf d diatur dengan Peraturan Pemerintah.

Berdasarkan penelitian penulis yang dilakukan di Yasasan Lembaga Konsumen Indonesia terkait pelanggaran yang dilakukan oleh Jasa Klinik Kecantikan atas informasi yang tidak dilengkapi dari tahun 2014 sampai dengan 2018 belum ada pelaporan terkait atas pelanggaran mengenai hak atas informasi terhadap bahan kosmetik. Adapun penyelesaian sengketa atas pelanggaran yang dilakukan oleh Jasa Klinik Kecantikan atas informasi yang tidak dilengkapi dalam prakteknya belum ada pelaporan mengenai pelanggaran tersebut hal ini dapat dikarenakan beberapa faktor berdasarkan penelitian penulis dilapangan 110 tanggapan 57,3\% diantaranya belum mengetahui adanya Undang - Undang Perlindungan Konsumen yang mengatur hak dan kewajiban pelaku usaha serta 
konsumen. Hal tersebut menyatakan dengan jelas tidak adanya laporan mengenai pelanggaran tersebut dikarenakan kurang pengetahuan masyarak mengenai UUPK.

Berdasarkan pelanggaran yang dilakukan oleh Jasa Klinik Kecantikan atas informasi yang tidak dilengkapi, konsumen dapat mengajukan gugatan atas pelanggaran tersebut. Gugatan dapat diajukan baik secara lisan atau pun tertulis disertai dengan pembayaran biaya administrasi. Uraian tentang kejadian merupakan penjelasan duduknya perkara, sedangkan uraian tentang hukum merupakan uraian tentang adanya hak atau hubungan hukum yang menjadi dasar yuridis atau tuntutan. Konsumen sebagai penggugat menguraikan dengan jelas hubungan hukum antara pelaku usaha dan konsumen sampai pada peristiwa adanya kerugian yang diderita konsumen. Hubungan hukum itu dapat berupa hubungan yang timbul karena adanya perjanjian (kontrak) atau dapat pula berupa hubungan hukum yang timbul karena terjadinya peristiwa melanggar hukum. Ada dua peristiwa yang dapat diajukan sebagai dasar hak konsumen untuk mengajukan tuntutan, yaitu peristiwa wanprestasi dan perbuatan melawan hukum (PMH). Pada bagian akhir gugatan dimuat petitum itu akan mendapatkan jawaban di dalam dictum atau amar putusan. (Janus Sidabalok, 2014:135)

Uraian tentang kejadian merupakan penjelasan duduknya perkara, sedangkan uraian tentang hukum merupakan uraian tentang adanya hak atau hubungan hukum yang menjadi dasar yuridis atau tuntutan. Konsumen sebagai penggugat menguraikan dengan jelas hubungan hukum antara pelaku usaha dan konsumen sampai pada peristiwa adanya kerugian yang diderita konsumen. Hubungan hukum itu dapat berupa hubungan yang timbul karena adanya perjanjian (kontrak) atau dapat pula berupa hubungan hukum yang timbul karena terjadinya peristiwa melanggar hukum. Ada dua peristiwa yang dapat diajukan sebagai dasar hak konsumen untuk mengajukan tuntutan, yaitu peristiwa wanprestasi dan perbuatan melawan hukum (PMH). Pada bagian akhir gugatan dimuat petitum itu akan mendapatkan jawaban di dalam dictum atau amar putusan (Janus Sidabalok, 2014 : 135). 
Setelah surat gugatan selesai dibuat maka tahap selanjutnya adalah melakukan pemeriksaan dan pembuktian peristiwa hukum yang mengakibatkan adanya kerugian. Sebagaimana ketentuan yang ada di dalam pasal 1865 KUHPerdata yang menyatakan bahwa pihak yang mendalilkan kesalahan maka dialah yang wajib membuktikan kesalahan tersebut. Gugatan yang ada didalam hukum perdata dapat berbentuk peristiwa wanprestasi dan perbuatan melawan hukum.

Jika penggugat menyatakan seorang tergugat telah melakukan wanprestasi maka pihak penggugat harus membuktikan kesalahan tergugat berupa:

1) Adanya hubungan perikatan yang berupa perjanjian.

2) Adanya bagian - bagian dari kewajiban yang tidak dipenuhi oleh pelaku usaha (tergugat).

3) Timbulnya kerugian bagi konsumen (penggugat).

Jika penggugat menyata pelaku usaha (tergugat) telah melakukan perbuatan melawan hukum, maka penggugat harus membuktikan kesalahan tergugat berupa:

1) Adanya perbuatan melawan hukum, baik berupa pelanggaran hak konsumen, pelanggaran terhadap kewajiban berhati-hati, pelanggaran norma kesusilaan, maupun pelanggaran norma kepatutan.

2) Adanya kesalahan dari pelaku usaha (tergugat), baik berupa kesalahan maupun kelalaian

3) Adanya sejumlah kerugian yang diderita konsumen (penggugat).

4) Adanya hubungan kausal antara perbuatan melawan hukum yang salah ini dengan kerugian yang diderita konsumen (tergugat).

Pada dasarnya penggugat mengemukakan suatu peristiwa itulah yang dibebani pembuktian. Akan tetapi, untuk mencapai keadilan, dalam praktik pembagian beban pembuktian itu baru dirasakan adil dan tepat apabila yang dibebani beban pembuktian adalah pihak yang paling sedikit dirugikan jika disuruh membuktikan. Hal ini berarti membebani kewajiban, hakim harus 
bertindak arif dan bijaksana tidak boleh berat sebelah. (Retnowulan Sutantio dan Iskandar Oeripkartawinata, $1989: 51)$

Gugatan wansprestasi ataupun perbuatan melawan hukum yang dibebani kewajiban untuk membuktikan kesalahan adalah penggugat. Namun dalam Hukum Perlindungan Konsumen sebagaimana Pasal 28 UUPK, yaitu Pembuktian terhadap ada tidaknya unsur kesalahan dalam gugatan ganti rugi sebagaimana dimaksud dalam Pasal 19, Pasal 22, dan Pasal 23 merupakan beban dan tanggung jawab pelaku usaha.

Hal ini merupakan cara baru dalam menuntut pertanggung jawaban terhadap pelaku usaha yang sudah dapat dibuktikan melakukan kesalahan tanggung jawab ini disebut dengan prinsip tanggung jawab mutlak. Jadi pelaku usaha langsung dibebani tanggung jawab sedangkan kesalahan tidak akan dipermasalahkan karena konsumen tidak perlu membuktikan kesalahan pelaku usaha tersebut.

Pasal 19 UUPK telah menyebutkan beberapa jenis ganti kerugian yang kemungkinan diakibatkan oleh kesalahan atau kelalaian pelaku usaha sehingga mendatangkan kerugian bagi konsumen.

Dalam penyelesaian sengketa konsumen dengan class action mekanismenya adalah kelompok yang bersengketa diwakili oleh satu, dua orang atau lebih bertindak untuk menyelesaikan sengketa tersebut. Gugatan perwakilan ini diatur khusus dalam PERMA Nomor 1 Tahun 2002 tentang Acara Gugatan Perwakilan Kelompok. PERMA ini mengatur tentang prosedur gugatan perwakilan yang terdiri dari enam bab.

Untuk mengajukan gugatan class action syarat-syarat formal yang harus dipenuhi berdasarkan pasal 3 PERMA Nomor 1 Tahun 2002. Dan tuntutan ganti rugi harus dikemukakan dengan baik dan tepat yang didalamnya memuat masukan mengenai adanya cara menyalurkan atau proses pemberian ganti rugi kepada keseluruhan anggota, disini sebaiknya dicantumkan juga mengenai saran terkait adanya usaha untuk membentuk suatu tim yang bertugas untuk lebih mempermudah proses penyaluran ganti rugi kepada orang yang berhak menerimanya. 


\section{Penutup}

\section{A. Kesimpulan}

1. Pelaksanaan pemenuhan hak atas informasi bahan kosmetik oleh pelaku usaha jasa klinik kecantikan yang diatur dalam Undang-Undang Nomor 8 Tahun 1999 tentang Perlindungan Konsumen sebagian besar sudah sesuai dengan apa yang diatur dalam Undang-Undang Perlindungan Konsumen, hanya saja dari hasil penelitian masih banyak menemukan kosmetik dari jasa klinik kecantikan yang tidak memberikan hak informasi terhadap bahan kandungan yang ada dalam kosmetik, padahal di dalam undang-undang perlindungan konsumen sudah diatur hak konsumen dimana konsumen berhak atas informasi bahan kandungan yang ada dalam kosmetik tersebut

2. Penyelesaian sengketa atas pelanggaran yang dilakukan oleh Jasa Klinik Kecantikan atas informasi yang tidak dilengkapi sengketa konsumen dapat ditempuh melalui pengadilan atau di luar pengadilan berdasarkan pilihan sukarela para pihak yang bersengketa.

\section{B. Saran}

Pemerintah harus lebih memperhatikan sistem operasi pelaku usaha khususnya jasa klinik kecantikan apakah telah sesuai dengan standarisasi nasional sebagai klinik kecantikan dengan cara lebih meningkatkan kembali terhadap pengawasan setiap pelaku usaha. Karena dalam prakteknya penulis masih menemukan jasa klinik kecantikan yang belum dapat memenuhi kewajibannya selaku pelaku usaha atas pemenuhan hak atas informasi bahan kosmetik. 


\section{Daftar Pustaka}

Harahap, Yahya. Beberapa Tinjauan Mengenai Sistem Peradilan dan Penyelesaian Sengketa, Bandung: Citra Aditya Bakti, 1997.

Kusuma, Mulyana W. Should Court - Annexed Alternative Dispute Resolution Mechanisms Mandatory? Jurnal Ilmiah Hukum Era Hukum, Nomor 1.1994 .

Kolonial,Evie. Bimbingan Konsumen (Direktoran PK Sebagai Fasilitator Dalam Penyelesaian Sengkete Konsumen), Jakarta : Dit. Perlindungan Konsumen, Dep.Perindustrian dan Perdagangan,2003.

Muthiah,Aulia. Aspek Hukum Dagang dan Pelaksanaannya di Indonesia, Yogyakarta: Pustaka Baru.2015.

Nasution, A.Z. Konsumen dan Hukum, Jakarta: Pustaka Sinar Harapan, 1995

Rahmawanti, Intan Nurdan Rukiyah Lubis, Win - win Solution Sengketa Konsumen, Yogyakarta : PustakaYustisia.2014.

Sidabalok, Janus. Hukum Perlindungan Konsumen di Indonesia, Bandung: PT. Citra Aditya Bakti, 2014.

Siahaan, NHT. Hukum Perlindungan Konsumendan Tanggung Jawab Produk, Jakarta : Panta Rei, 2005.

Sutantio, Retnowulan dan Iskandar Oeripkartawinata, Hukum Acara Perdata Teori dan Praktek, Bandung: Alumni, 1989.

Widjaja, Gunawandan Ahmad Yani, Hukum tentang Perlindungan Konsumen, Jakarta : Gramedia, 2003.

Wignjosoebroto, Soetandyo. "Hukum dan Metode-metode Kajiannya”, dan "Penelitian Hukum : Sebuah Tipologi”, Jakarta, 1980.

Indonesia . Undang-undang Dasar Negara Republik Indonesia Tahun 1945. Kitab Undang-undang Hukum Perdata Undang-Undang Nomor 8 Tahun 1999 tentang Perlindungan Konsumen. 